\title{
Initiative Analysis to Enter into Potential and Restricted Market: Small, Medium and Largest Enterprises Having Chance into a Virgin Market: Latin American (CELAC) and China (Practical, China Case)
}

\author{
Rick Fernandez Hurtado, S. ${ }^{1}$ \\ ${ }^{1}$ School of Management, Shanghai University, Shanghai, China \\ Correspondence: Rick Fernandez Hurtado, S., School of Management, Shanghai University, 99 Shangda Road, \\ Shanghai 200444, China. Tel: 86-138-1793-1651. E-mail: saulrick@163.com
}

Received: November 27, 2012

Accepted: December 31, 2012 Online Published: January 15, 2013

doi:10.5539/ijbm.v8n3p103

URL: http://dx.doi.org/10.5539/ijbm.v8n3p103

\begin{abstract}
It has been argued that the Chinese market is a potential consumer of overseas products, and several documents identify the opportunities and risks that the Chinese market also represents. Nevertheless, on one hand, it Commercial Cluster Integration Initiative would create more opportunities for Latin American economies (review the formula that clarifies how the Chinese market operates their strategic prices, Chapter 1, Prices Equation) to follow up as example.On other hand, the CELAC could benefit from more opportunities with the Chinese internal market and at the same time these countries would increase their economies. In this way, LAC-Latin American Countries could reduce its unemployment rate.

This study will look at the feasibility of a Commercial Cluster Platform CCP-Commercial Cluster Platform between LAC countries to work freely at internal Chinese market. The formulated research question will explore the various advantages and measures to manage SEN-Strategic Enterprise Networking.

This dissertation evaluates the possibility of management LACI-Latin American Commercial Integration; to reach a common free agreement as part of the Chinese approach to new preferential trade agreements characterized by the term competitive liberalization. It bases on the idea that competition among large countries (US/EU) in negotiating preferential arrangements with smaller countries or regions will lower barriers, and eventually add fresh impulse to new multilateral WTO negotiations.
\end{abstract}

Keywords: commercial, clusters, integration, CELAC, platform, initiative, SCM

\section{Introduction}

\subsection{Introduction to Study}

A typical commercial cluster comprises SMEs (Lamming et al., 2000). SMEs could benefit from commercial clusters network model, when implemented with minimal changes to the existing commercial processes. Lamming et al. (2000) argue that such a model requires a framework integrating all the components using component relationships at an operational level. As such, there is a need for a framework in CCII-Commercial Cluster Integration Initiative as a foundation for development of model(s) of industry applications. This research describes the development of an integrated framework for CCII-Commercial Cluster Integration Initiative, and contributes to the knowledge of potential improvements and developments in commercial processes. The framework becomes a foundation for model developments in many industry applications, using individual networks.

\subsection{Background of this Research}

However, despite trading regulation to protect internal market and other commercial limiting measures and political constraints that some countries manage at domestic process, global commercial warfare competition is increasing rapidly and the information is the most important revolution part in this process. As Clark and Fujimoto (1991) states, "Few things so stimulate economic growth as the rapid development of information, whether telecommunications, computer data, computer network, or entertainment media".

In fact, since the early 1980s, there has been a significant improvement in the amount of strategic cluster signed between several enterprises and/or countries. On one occasion (1980-1990), Japanese enterprises celebrated over 
five hundred (500) commercial clusters with United States enterprises (Prahalad et al., 2001). Moreover, the goal of cluster network has also been seen. It is important to mention that strategic networks of the ASEAN-Association of Southeast Asian Nations was founded on 1967, August the $8^{\text {th }}$, by several Asia countries such as Malaysia, Singapore, Thailand, Philippines and Indonesia.

The explanation why strategic commercial cluster remains so famous is because of the appeal of flexibility, informality and effectiveness between each single CCII-Commercial Cluster Integration Initiative member. Technology becomes complex and costly, and potential customers demand more integration. This explains why enterprises appear to build strategic commercial cluster in a record quantity.

Due to the complication of going alone, regional competitors must join in strategic cluster platform to reach common aims such as:

Table 1. Common objective on strategic CCII-commercial cluster integration initiative platform

$\begin{array}{ll}\text { 1. Increase the productivity of the group companies } & \text { 2. Drive innovation in the field } \\ \text { 3. Encourage new enterprises in the field } & \text { 4. Reduce opportunistic behavior } \\ \text { 5. Increase the pressure of coordination between undertakings } & \text { 6. Advancement } \\ \text { 7. Sharing production } & \begin{array}{l}\text { 8. Research facilities, and the international supply chain } \\ \text { market to ensure market growth }\end{array}\end{array}$

Sources: own research data, 2012, common objective on strategic CCII-commercial cluster integration initiative platform

Current efforts of each country are resulting towards CCII-Commercial Cluster Integration Initiative worldwide, which is becoming an increasing complex relationship network because a single country will not find an easy way to access a strict international market by itself (e.g. China). R\&D clusters network are increasing in every single industry, including each single international country.

\subsection{Commercial Cluster Integration Initiative Framework}

Enterprises claim that countries integration on market operations is essential for the type of international supply chain development. Primarily, the reason could be that enterprises place reliable large volume of merchandise punctually on the destination market. It is crucial on the market that never runs out of stock. Strict markets (China as example) have strong commercial mechanisms if their customers would experience supply shortage. The main objective of the CCP-Commercial Cluster Platform is to maintain punctuality, reliable delivery and low-cost on supply chain. CCII-Commercial Cluster Integration Initiative partnership is essential, since any issue on the strict market can be solved between members of CCII-Commercial Cluster Integration Initiativeplatform (CELAC, 2011). e.g., everything in the distribution chain management has a high cost, including international and internal logistics management cost. Cluster integration partnership minimizes direct and indirect costs as well as delivery time, and maximizes offer of quantity as regional market participation.

However, several countries such as Chile, Peru, Costa Rica, Mexico and Colombia have FTAs with this potential market referenced by this study. In this single way, enterprises of each country have the opportunity to access markets without many difficulties, but still manage a cluster integration partnership to minimize risk and maximize market supply. Governments as well should have the responsibility on the commercial platform. This requires organizing the platform in order that enterprises may have more international commercial support. (Merchant and Otley, 2007). 


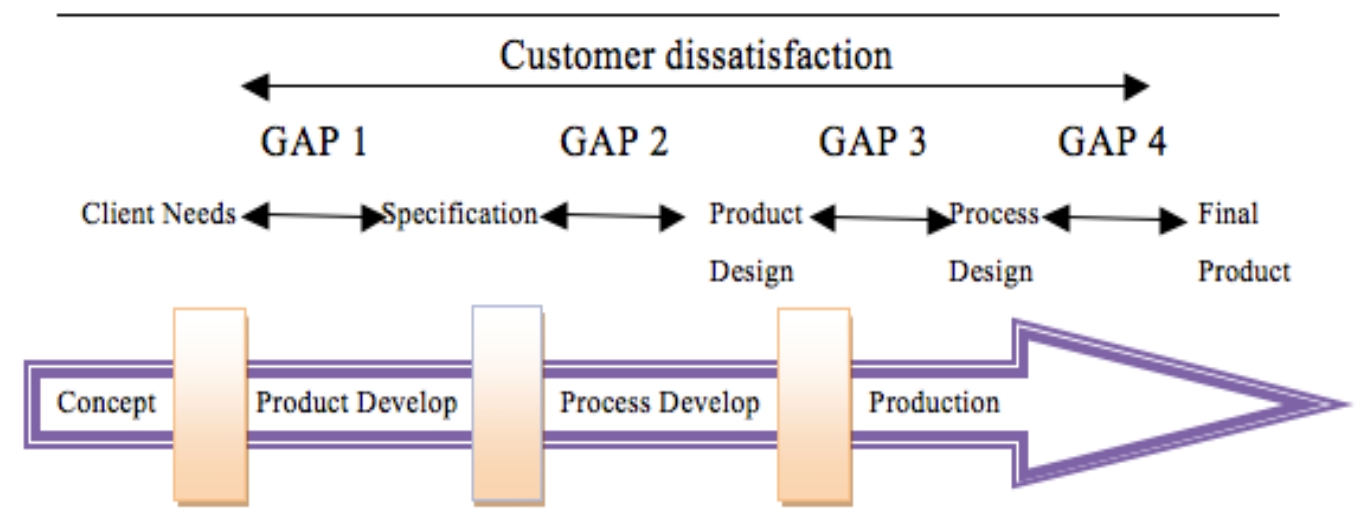

Own Research Data, 2012, Conceptual model of the relationships among cluster variables

Figure 1.Conceptual model of the relationships among cluster variables

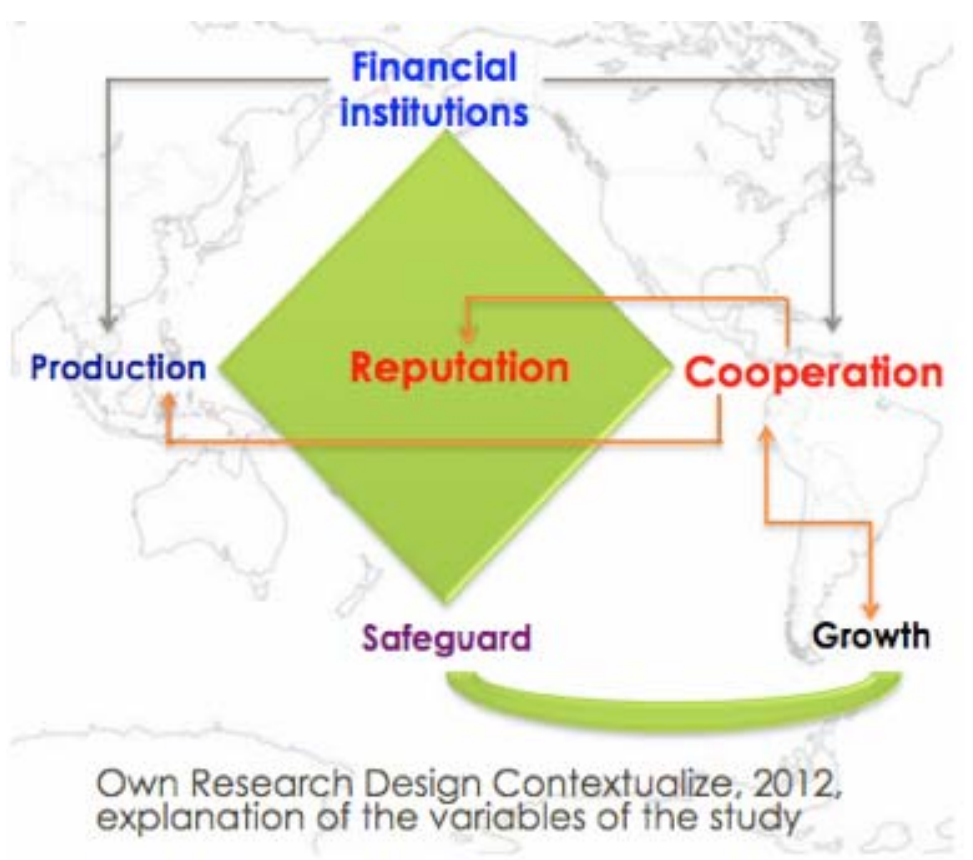

Figure 2. Explanation of the vraiables of the study

\subsection{Historyof the Economics of CELAC and China}

\subsubsection{The Organization of Latin American States}

On February 23, 2010, Latin American leaders at the 23rd Rio Group summit in Playa del Carmen, Quintana Roo, Mexico, stated that they were forming an organization of Latin American and Caribbean nations. Once its charter was developed, the group was formally established in July, 2011, at a summit in Caracas. The bloc was the main forum for political dialogue for the region, without the United States and Canada.

CELAC's inaugural summit was due to be held in mid-2011. The summit was instead held on December 2 and 3, 2011 in Caracas - Venezuela. It primarily focused on the global economic crises in the United States and Europe at the moment, and was evaluating its effects in the Latin American region. Several leaders, including Cristina Fernandez(Argentina President 2011-2015),DilmaRousseff(Brazil President 2011-2014)and Juan Manuel Santos (Colombian President 2010-2014), encouraged an increase in regional commercial trade, economic development, and further economic cooperation among members in order to defend their growing economies.CELAC is made up of 33 countries in Latin America and the Caribbean without the presence of the United States and Canada. 


\subsubsection{Chinese Government Support}

Chinese president, Hu Jintao(China President 2002-2012), sent a message to Venezuelan president, Hugo Chavez, and Chilean president, Sebastian Pinera, last year to congratulate the founding of the CELAC. In this message, Hu said that the establishment of CELAC is a major milestone in regional integration and that China appreciates the positive role of Latin American and Caribbean countries in international and regional affairs.

In its own dealings with Latin America, China promotes a "win-win" policy of "mutually beneficial" interaction. Ex-President Hu Jintao made no official visits to specific Latin American countries in 2011, but President Xi Jinping(China President 2012-2017) visited Cuba, Uruguay, and Chile, where he reached a number of primarily investment and/or trade-based agreements with the countries' leaders.

China has established its own free trade agreements with three countries in Latin America - Chile, Peru, and Costa Rica. The Costa Rican FTA came into effect on August 1, 2011. According to Costa Rican press, China and Costa Rica have been working ever since to implement its various provisions. The FTA currently enables over 60 percent of the countries' products to enter each other markets duty-free. Chinese textiles, machines, electric appliances, vegetables, fruits, automobiles, chemical products, raw fur and leather exports are expected to benefit from the agreement. Costa Rica should see higher sales of coffee, beef, pork, fruit juices and jam in the Chinese market. China also maintains bilateral investment protection agreements and bilateral tariff reduction agreements with certain countries in the region, most of which were implemented in the mid-1990s or early 2000s.

\subsubsection{China is the Most Dynamic Economy}

As a destination for exports, China became more important in 14 of the 17 countries analyzed and was among the top five destinations for seven countries: Argentina, Venezuela, Brazil, Chile, Costa Rica, Peru and Uruguay. As an origin for the region's imports, China moved up the ranking for almost all the countries and was among the top five origin countries for 16 of the 17 countries analyzed (the exception is Honduras, but even there China is ranked as the sixth largest source of imports).

In our empirical analysis, we essentially tested whether Chinese exports to a particular country in a given category are affecting LAC exports to a greater extent than exports from other countries, controlling for overall exporter supply growth.

\subsection{China \& Latin American and the Caribbean Entering to a New Commercial Relationship}

China economic growth vs. Latin America is an important consideration. Both economies can be considered emerging markets, where rapid growth of the economy can be seen. China's growth is significant but Latin America offers several benefits as well. Latin America is not a formal economy itself; rather it is those countries where Spanish or Portuguese are spoken. Countries included here are Mexico, Central American countries and South American countries, as well as the Dominican Republic, Puerto Rico, Cuba and the Caribbean.

As mentioned earlier, the integration includes 33 countries as seen on the following table, which indicate several statistics.

Table 2. Indicate the country's global position

\begin{tabular}{|c|c|c|c|c|c|c|c|c|c|c|c|c|}
\hline Country & Area $\mathrm{Km} 2$ & $\begin{array}{c}\text { Population } \\
2011\end{array}$ & $\begin{array}{c}\text { GDP } \\
\text { (PPP) } \\
\text { million } \\
2010\end{array}$ & $\begin{array}{c}\text { GDP } \\
\text { Per } \\
\text { Capita }\end{array}$ & HDI & FSI & CPI & IEF & GPI & WPFI & DI & $\begin{array}{c}\text { Income } \\
\text { Inequality }\end{array}$ \\
\hline $\begin{array}{l}\text { Antigua and } \\
\text { Barbuda }\end{array}$ & 443 & 87,884 & 1,425 & 16,400 & 0.764 & 59.9 & N/A & N/A & N/A & N/A & N/A & $\mathrm{N} / \mathrm{A}$ \\
\hline Argentina & $2,780,400$ & $41,769,726$ & 596,000 & 14,700 & 0.797 & 46.8 & 3 & 51.7 & 1.852 & 16.35 & 6.84 & 45.8 \\
\hline Bahamas & 13,880 & 313,312 & 8,921 & 28,700 & 0.771 & 56.5 & 7.3 & 68 & N/A & N/A & N/A & N/A \\
\hline Barbados & 430 & 286,705 & 6,227 & 21,800 & 0.793 & 52.8 & 7.8 & 68.5 & N/A & N/A & N/A & N/A \\
\hline Belize & 22,966 & 321,115 & 2,651 & 8,400 & 0.699 & 67.7 & N/A & 63.8 & N/A & N/A & N/A & N/A \\
\hline Bolivia & $1,098,581$ & $10,118,683$ & 47,880 & 4,800 & 0.663 & 82.9 & 2.8 & 50 & 2.045 & 28.13 & 5.92 & 57.3 \\
\hline
\end{tabular}




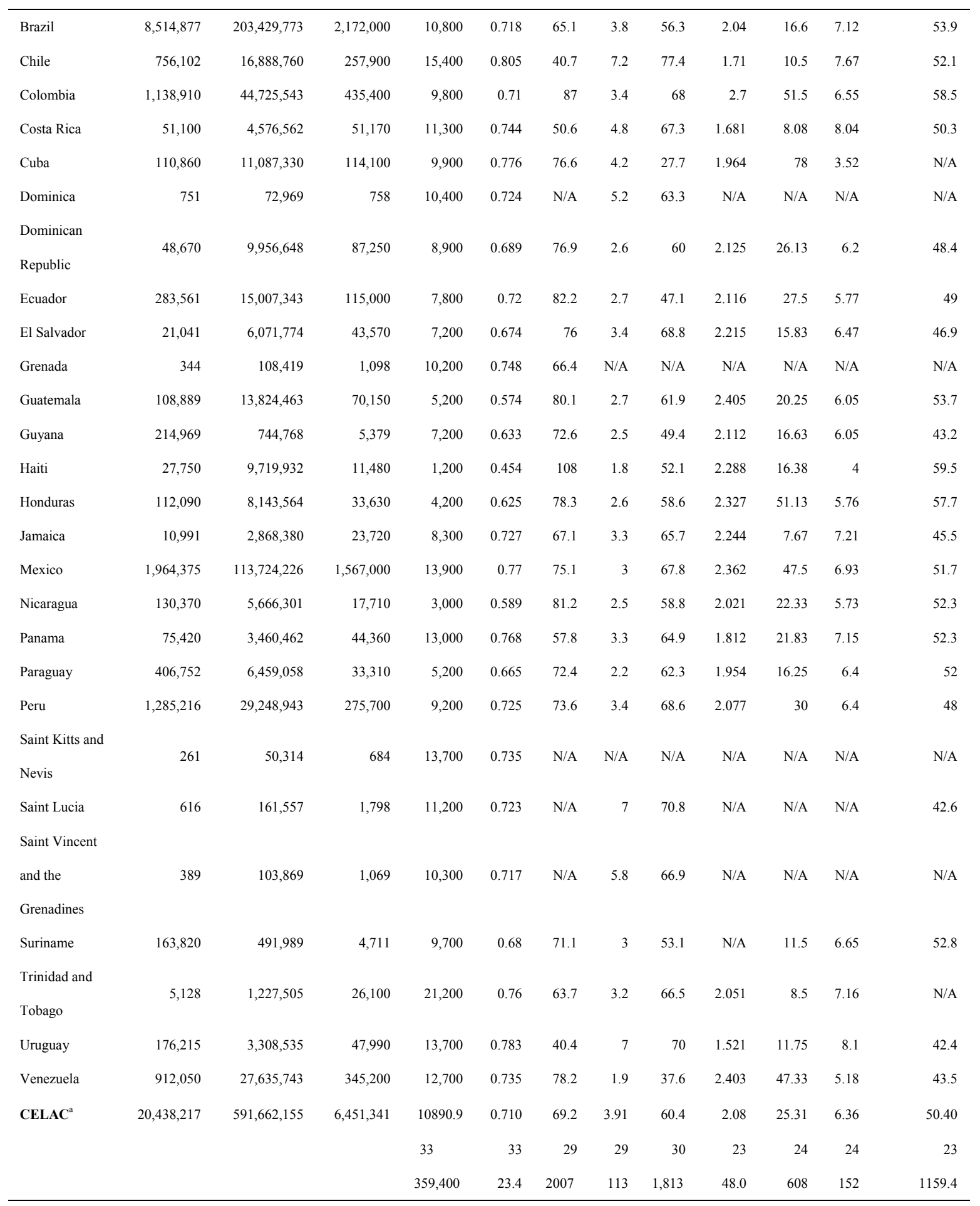

Sources: Wikipedia, the free encyclopedia, and Own Calculation Researcher Data, 2012, indicate the country's global position

\subsubsection{China has become a Key Commercial Partner for CELAC}

As previous formula and figure showed, it can be assured that China has gained a major share in the region's trade, while the United States and the European Union continue to lose relative share. In the 2006-2010 period, the region's exports to China grew five times faster than those to the overall world. This makes China a key commercial partner for CELAC countries. In 2010, the region's exports to China amounted to $8 \%$ of its total exports, compared to a $41 \%$ share going to the United States and $13 \%$ to the European Union (27 countries). 


\begin{tabular}{|c|c|c|c|c|}
\hline \multicolumn{5}{|c|}{$\begin{array}{l}\text { China: average annual growth rate of trade, } \\
\text { (Percentages) }\end{array}$} \\
\hline & \multicolumn{4}{|c|}{ Exports } \\
\hline & 1990-1995 & $1995-2000$ & $2000-2005$ & $2005-2010$ \\
\hline $\begin{array}{l}\text { Latin America and } \\
\text { the Caribbean }\end{array}$ & 322 & 17.8 & 26.8 & 31.0 \\
\hline Asia-Pacilica & 26.5 & 9.3 & 20.3 & 13.8 \\
\hline United States & 36.7 & 16.1 & 25.6 & 11.7 \\
\hline European Union & 26.3 & 15.0 & 28.8 & 16.4 \\
\hline Rest of the world & 8.6 & 7.1 & 26.6 & 17.2 \\
\hline \multirow[t]{2}{*}{ World } & 19.1 & 10.9 & 25.0 & 15.7 \\
\hline & \multicolumn{4}{|c|}{ Imports } \\
\hline $\begin{array}{l}\text { Latin America and } \\
\text { the Caribbean }\end{array}$ & 14.5 & 12.7 & 37.6 & 27.7 \\
\hline Asia-Pacilica & 324 & 12.2 & 23.9 & 14.6 \\
\hline United States & 19.7 & 6.8 & 16.8 & 15.9 \\
\hline European Union & 18.2 & 7.6 & 18.8 & 17.9 \\
\hline Rest of the world & 11.2 & 13.4 & 26.8 & 15.8 \\
\hline World & 19.9 & 11.3 & 24.0 & 16.1 \\
\hline
\end{tabular}
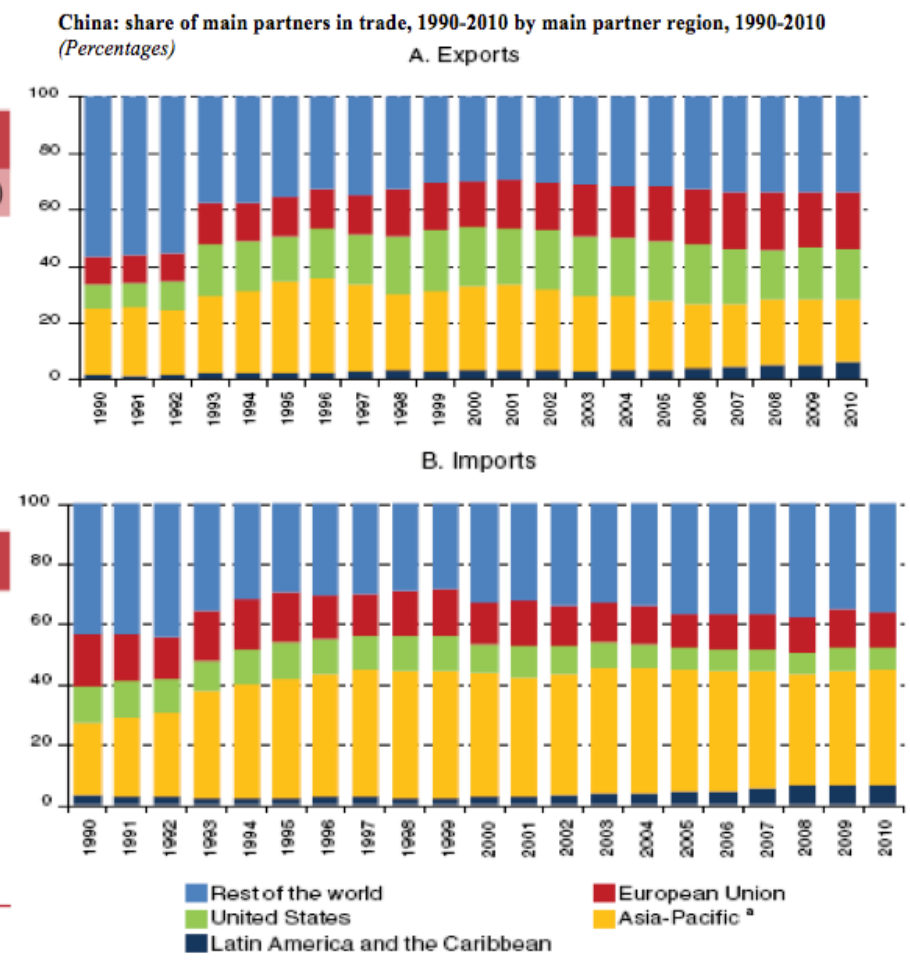

Figure 3. China average annual growth rate $\&$ the share of main partners in trade 1990-2010

Source: Economic Commission for Latin America and the Caribbean (ECLAC), on the basis of United Nations Commodity Trade Data Base (COMTRADE) for 1990, 1995, 2000 and 2005, and International Monetary Fund (IMF), Direction of Trade Statistics for 2010. The Association of Southeast Asian Nations (ASEAN), Australia, Japan, New Zealand and Republic of Korea included.

In other hand, China is a larger commercial partner for the region on the import side than on the export side, which has led to widening bilateral trade deficit. Forecasts indicate that China will overtake the European Union as the region's second largest source of imports. In this trade dynamics, China has gained an increasingly important role, both in exports and imports, and has quickly surpassed Japan as Asia-Pacific's main commercial partner.

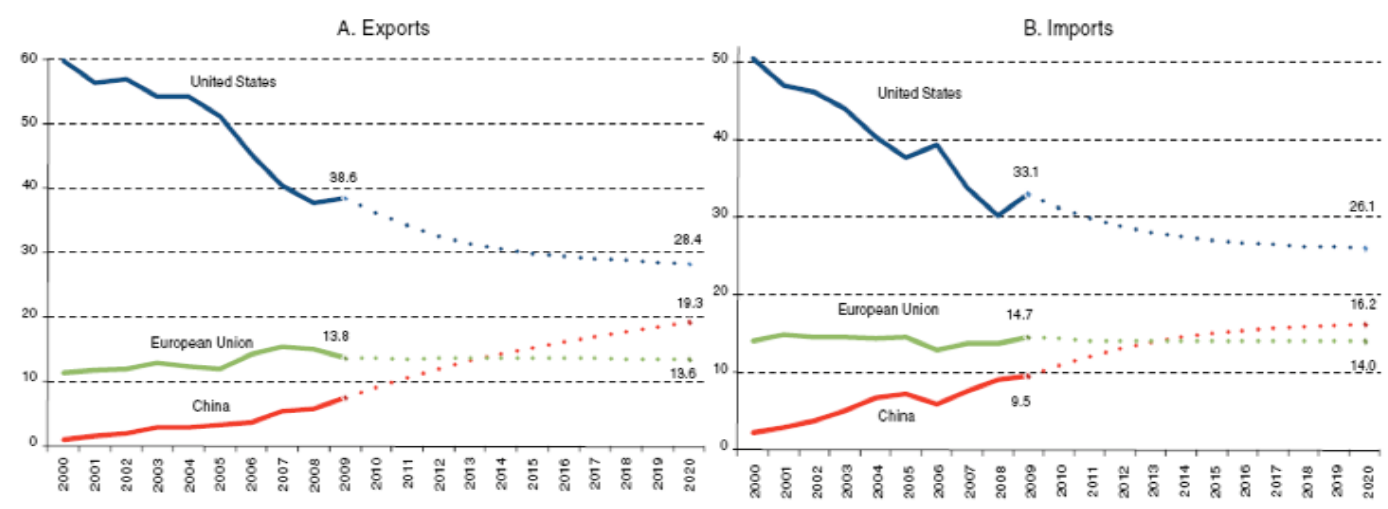

Figure 4. Latin American and the Caribbean: share of each main partner in total trade percentages (2000-2020)

Source: Economic Commission for Latin America and the Caribbean(ECLAC), on the basis of United Nations Commodity Trade Data Base (COMTRADE) and national soucrces for 16 countries: Argentina, Bolivarian Republic Of Venezuela, Brazil, Chile, Colombia, Costa Rica, Ecuador, El Salvador, Guatemala, Honduras, 
Mexico, Panama, Paraguay, Peru, Plurinational State Of Bolivia And Uruguay. Estaimates and projections are based on GDP growth rates between 2000 and 2009 for Latin America and the Caribbean, Asia-Pacific, China, the United States, the European Union and the rest of the world. Forecasted growthe of exports and imports are assumed to converge with the respective economics' long-term GDP growth rate.

The increase in imports from China will be led by purchases of capital goods, particularly electronic items, auto-parts, equipment and machinery, and textiles. These Chinese products already have a strong presence in the region's markets. Some countries in the region have relatively weak trade relations with China, despite its evident importance as a trading partner.

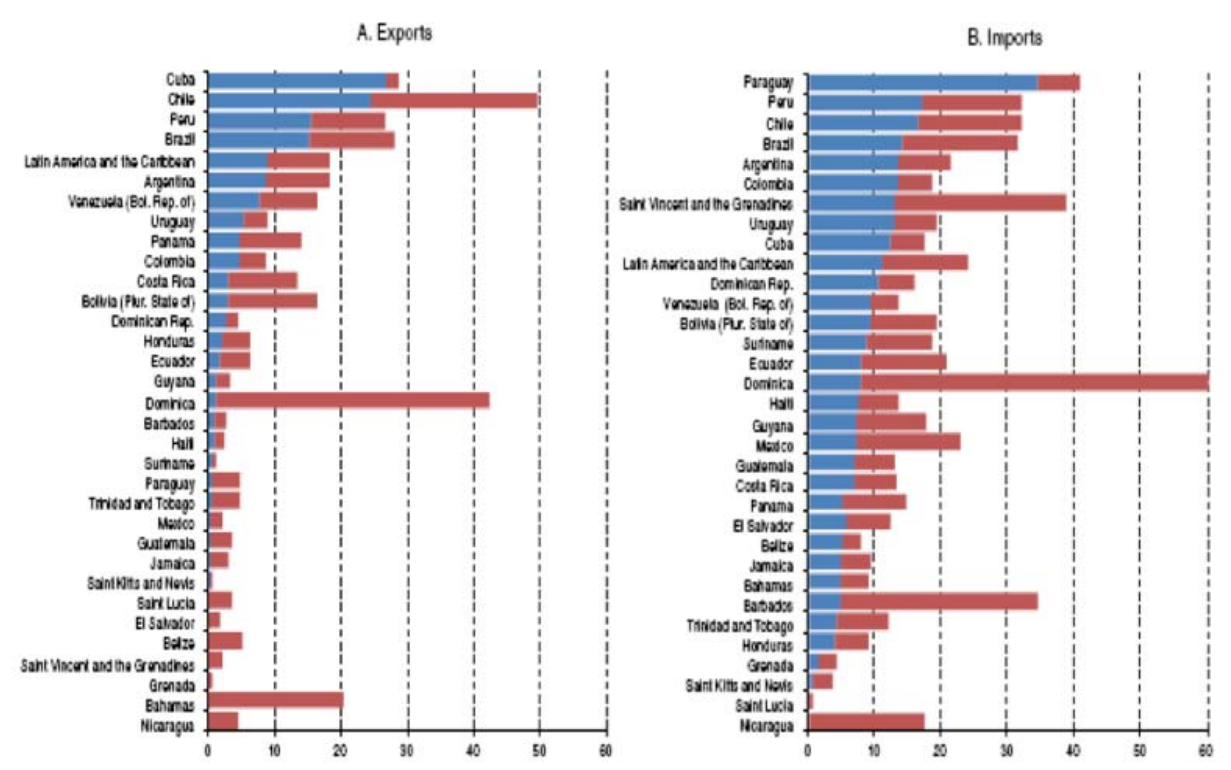

Figure 5. CELAC: share of Asian-pacific and China in trade (2010)

Source: Economic Commission for Latin America and the Caribbean (ECLAC), on the basis of United Nations Commodity Trade Data Base (COMTRADE) for 2000 and official country data for 2010. Another Asia includes Hong Kong SAR. China refers only to the people's Republic of China. Data for the Caribbean countries (except for Dominican Republic) are from the International Monetary Fund (IMF), Direction of Trade Statistics.

The importance of China as a market for the region's exports varies significantly from country to country in CELAC. Since the beginning of the 1990s, China has become a key export destination for Cuba, Chile, Peru, Brazil, Argentina and Venezuela (in order of China's importance as a destination for each country's exports). The importance of China is even greater if trade through Hong Kong Special Administrative Regions (SAR) is considered.

\subsubsection{The Objective of this Research}

What causes the actual economic crisis in some countries as US and Europe has been previously described. This situation has led to a breakdown of this research to find out key points to manage international networks/clusters on the international and strict markets to avoid critical economic situations. An advantage of the study of CCII-Commercial Cluster Integration Initiativeplatform could be that CCII-Commercial Cluster Integration Initiative can be an alternative vehicle to help enterprises (CELAC, 2011) on development market and raise efficiency of their industry. Moreover, universal economic trends and the difficulties involved with gaining access to foreign markets have meant that strategic cluster integration activities have proliferated. Enterprises of different industries of Latin America have become international style over the years; strategic network activity in this area has increased. The focus of this research is also to integrate and build the joint cooperation in CELAC between regional enterprises, according to the structure of members, and to obtain the satisfaction of enterprises that would enjoy the Commercial Clusters Integration Initiative.

This point of view will refer to these enterprises networks as competitors and/or customers. Finally, the study will evaluate the level of performance outcome, and the perception of the country (enterprises) members' 
behavior, whereas most prior studies have examined only several results in this type of commercial cluster relationship. As a whole, this research tries to answer several important questions such as:

- Can the countries integration reduce time and cost on destination supply chain?

- Is the enterprises cooperation able to increase each single enterprise's competitiveness at international market?

Information collected during this doctoral study provides measurable and verifiable information (see author credits), thus allowing reliable economic projections.

In order to accomplish these proposed objectives, this research is organized into four more chapters.In the first chapter the point of interest of this research has been explained (attraction of CCII-Commercial Cluster Integration Initiative platform and the important alternative choice made to strengthen enterprises to be developed in the current economic crises). Chapter two delineates the notion of strategic cluster integration platform. Chapter three provides the theory and hypothesis used. Chapter four addresses the methodological basis of this research, and then presents a discussion of the results. Chapter five discusses the findings of this research and concludes by identifying practical implications and future research.

\section{Literature Review \& Hypotheses}

This chapter is organized into five parts. The first part presents the literature review on strategic CCII-Commercial Cluster Integration Initiative and an overview of know-based cluster, especially the origin of CELAC countries and China market commercial cluster cooperation together with prior studies related to these types of commercial cluster and knowledge transfer performance. The second part includes the theoretical framework and empirical literature concerning those factors affecting the effectiveness of knowledge transfer transaction cost and government networking support. The third part presents the modeling development \& hypotheses. The fourth part shows independent variables, mediating variables and dependent variables, and, the last part looks at the research hypotheses of the study.

\subsection{Overview of the Cluster Strategic Platform}

Consequently, enterprises change commercial resources to reduce risk and maximize their market industry (Tom Davenport, 2005); (Power, 2007b; Daconta et al., 2003; Business Objects SA (2007). Researchers are considering that CCII-Commercial Cluster Integration Initiativeand strategic absorption cooperation networking are market mechanisms alternative. According to these researchers, it would be necessary to implement CCII-Commercial Cluster Integration Initiative between countries worldwide (CELAC, 2011) and potential market (e.g. China) with an objective to address a specific strategic market. In addition, as researchers mention, enterprises are making clusters in order to secure and survive in the market sector.

Secondly, several researchers have focused and studied the framework of strategic clusters implementation, Sala-i-Martin and Artadi, 2004; Sarkis, 2003; Karsak et al., 2002). Strategic clusters can be managed in a variety of forms. In this study we focus on CCII-Commercial Cluster Integration Initiative platform, case in which countries would play important roles on the potential and strict market (e.g. China). Also, researchers mention several models cooperation forms such as JVs, Joint R\&D, joint Production; marketing and promotion, supplier partnership, supply chain agreements as stated by Lapadat (2009, p. 927). In the typical networking absorption cooperation most of the researchers have focused on the dichotomy of equity absorption cooperation vs. non-equity absorption cooperation (Ireland et al., 2001; Stake, 2008; Yin, 2008; Miles and Huberman, 2005) and several studies have seen differences in equity networking (Trusov et al., 2009; Sweeney et al., 2008; Dellarocas, 2003). The ways of normal networking CIP are unilateral. This means that the enterprises transaction focus on contract of property rights. The key feature here is that countries CCII-Commercial Cluster Integration Initiativeplatform (CELAC, 2011), can join together for external supply chain managing strict market (e.g. China). On the other hand, countries of (CELAC, 2011) that already have FTA with this potential market (China) could be member of CCII-Commercial Cluster Integration Initiative platform with an objective of the study (develop Chinese supply chain) and this potential market (China) could access to those countries of (CELAC, 2011) with low logistics and tariff restriction. In that commercial platform, governments are required to pool resources and work together for enterprises benefit (Osterle et al., 2001). In comparison to this policy (CCII-Commercial Cluster Integration Initiative platform, bilateral policy agreements are usually incomplete and more open-ended.

\subsubsection{Clusters Integration: Definition and Types}

Over the last 10 years there has been considerable attention placed on the changes occurring in the enterprises environment. Of particular interest has been change in the nature of relationships. The new forms of 
relationships have referred to partnerships (Aaker et al., 2004), (Hennig-Thurau et al., 2002), (Garbarino and Johnson, 1999), (Schau et al., 2009), (Fournier and Lee, 2009), (Zhang and Bloemer, 2008); network, argued by Agndal and Axelsson (2002, p. 448), D’Souza (1993), McDougall et al. (1994), Bell (1995), Poon and Jevons (1997) and Coviello\& Munro (1997); and in this point and CCII-Commercial Cluster Integration Initiative (Hu et al., 2005; Chen et al., 2006; Lai and Shyu, 2005).

Table 3 summarizes the definitions of clusters in several aspects. It points out relevant definitions developed bya number of scholarsto ensure that clusters in different industries are one of mutual benefit for every single party involved. In this research, clusters in commercial integration networks are defined as two or more partners/agreements that will carry out specific international chain supply market and, the purpose is the establishment of strategic relationships between governments to promote and implement networking commercial platforms and enterprises that share compatible goals, strive for mutual benefits, and acknowledge at a high level of mutual cooperation.

To understand more about clusters, the next section will explain why clusters in different industries are established, drawing on the different points of view stated in many academic papers published in the field.

Table 3. Four cluster's type

\begin{tabular}{cc}
\hline type & Definition \\
\hline $\begin{array}{c}\text { Geographical cluster } \\
\text { Sectoral clusters }\end{array}$ & $\begin{array}{c}\text { As we are studying in this recently research } \\
\text { A cluster of commerical resources operating together within } \\
\text { the same commercial sector }\end{array}$ \\
Verizontal cluster & $\begin{array}{c}\text { Interconnections between businesses and a sharing of } \\
\text { resources level eg. Knowledge management }\end{array}$ \\
i.e. a supply chain cluster, the main idea of this study research.
\end{tabular}

Sources: Das and Teng,2000: 34. As shown in table 2, type of cooperation of clusters can be classfied according to the firm's available resources.

\subsubsection{The Dynamic Processes of Commercial Clusters Networking}

Today's enterprises in every industry agreement are highly dynamic and uncertain. So, given these circumstances, enterprises of high-level governments are looking for feasible solutions to reduce in different measure risks in international markets. CCII-Commercial Cluster Integration Initiative can develop bargaining power at a high level, the moment that government provides support in the clusters commercial network; enterprises would be able to handle a potential and strict international market. Several researchers have focused only on studied "why firms do establish cooperation between enterprises until engaged absorption"; this research concludes that there are several main important theoretical approaches that explain the motivation for entering into CCII-Commercial Cluster Integration Initiative:

1) Transaction Cost Theory;

2) Strategic Approach;

3) Organizational Learning \& Knowledge, and

4) The resource-based view perspective.

The clusters integration networking scenarios represent the second dimension of CCII-Commercial Cluster Integration Initiative (Prahalad et al., 2001). The enterprises that would work together should be from the same region (CELAC, 2011), as in the first case mentioned. Every country has to increase the number of enterprises in the same industry in order to cooperate with similar enterprises that have similar commercial resourcesRick Fernandez Hurtado, S., \& Pablo Betancur Agudelo, J.(2012).Networking constitutes the next dimension of CCII-Commercial Cluster Integration Initiative Platform. Often, it is targeted among enterprises/manufactures and governments (as in this case study). The cluster countries integration (CELAC, 2011) enables enterprises to manage international agreements more easily with a high level of trust. 


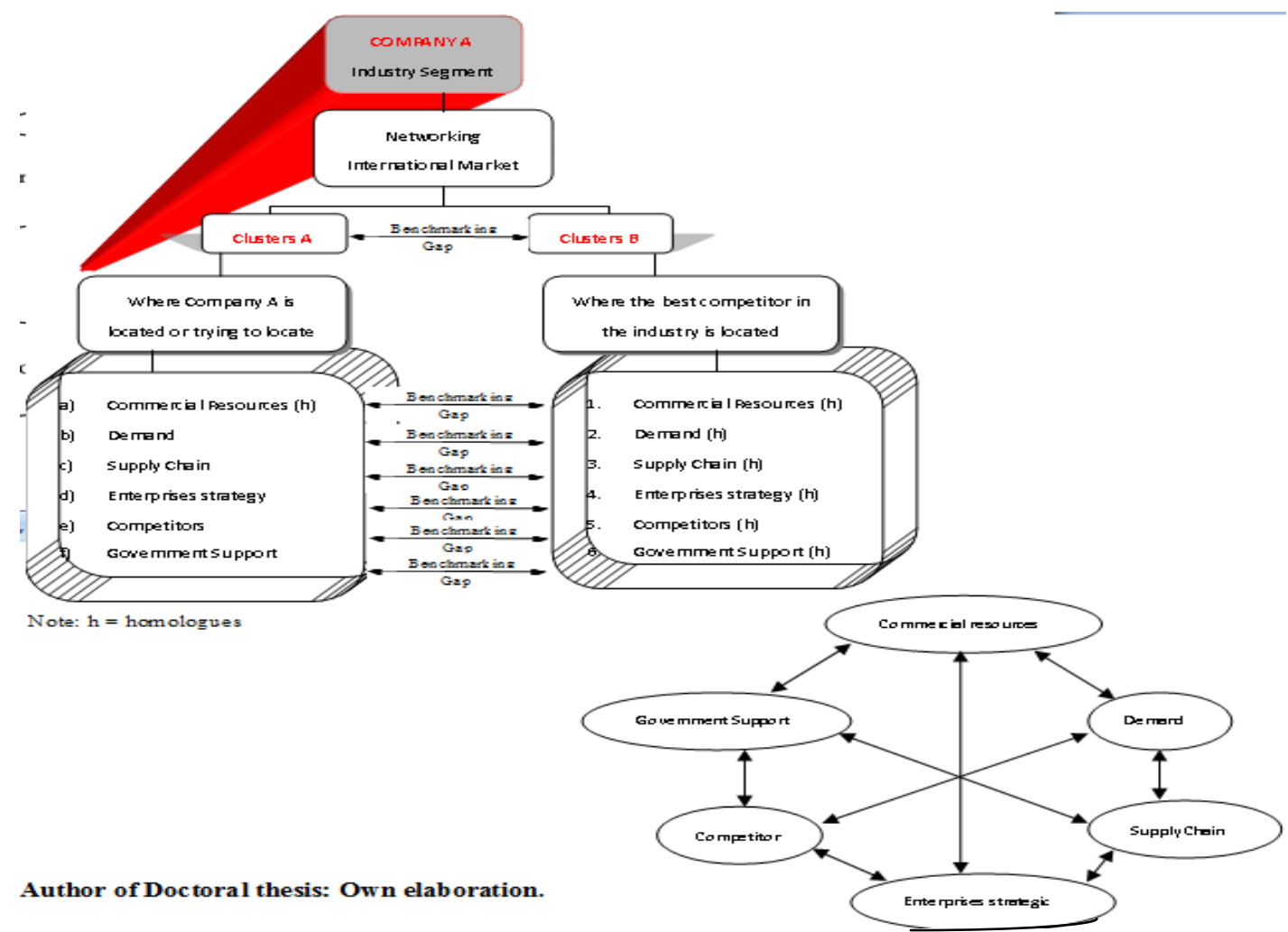

Figure 6. Enterprises Networking \& Cluster Environment

Sources: own research data, 2012, Enterprises Networking \& Cluster Environment

Moreover, in order to implement cluster integration network it is necessary to first analyze countries economy capabilities on several measurements such as technology, R\&D, Commercial Balance, Investment level as so on, in order to freely join the integration. These parameters are influencing factors to develop CCII-Commercial Cluster Integration Initiative platform seeking immediate competitive advantages in the focus market. In this sense, each party can contribute to the specific commercial resources with an objective to gain competitive advantage or even to help each other with products and market expansion (Prahalad et al., 2001).

\subsubsection{The Motivation of Enterprises on Domestic \& International Market (Venture)}

In current studies, transaction cost has been used over time as frequency devices in the decision making to manage integration market networks, where different timing and production methods can have a directly or indirect effect on transaction cost in commercial clusters integration platform as mentioned earlier. Findings on TCT-Transaction Cost Theory, argued by Williamson $(1975,1985)$, examines the relative costs and benefits in integration partnership and, more importantly, the understanding that those costs vary depending on the market objectives and decision making of the integration membership. This theory is usually referred to as the internationalization theory in the international trade relation literature (Stauss and Schoeler, 2004; Johnston, 2001). The term has been employed extensively in order to evaluate enterprises and multinational companies' performance (Paik et al., 2000). TCT-Transaction Cost Theory argues that regional integration networks and CCII-Commercial Cluster Integration Initiative platform involve transaction costs. Regional integration network transaction costs are higher than that of CCII-Commercial Cluster Integration Initiative platform. Conversely, it is also true that integration networks between regional integration and CCII-Commercial Cluster Integration Initiative platform performance is moderated by the transaction costs of collaboration network to the transaction costs of internalization.

TCT-Transaction Cost Theory has been discussed in the international literature and marketing research. In this way, it makes sense that TCT-Transaction Cost Theory has to be implemented within international economics and initiative network fields.

\subsubsection{General Aspects of Transaction Cost}

From 1970's to date, transaction cost has been used as a pioneering theory for enterprises to evaluate their own 
market development, as mentioned by Williamson (1975). Other theories are been used gradually. They are usually based on the concept of transaction costs that include transaction cost economics of Williamson (1985). The multinational enterprises behavior in economics transaction cost approach is a necessary argumentative point.

Many scholars have studied TCT-Transaction Cost Theory, especially after Williamson launched his studies on (1975); then, these theories became a popular worldwide. Transaction Cost Theory has been a method to analyze many areas of studies such as supply chain, clusters, etc.Transaction Cost Theory is observed in clusters markets hierarchy. Martins and Viedma (2004) argue that this happens when transaction cost is involved with a specific exchange, so high to compare with competence in the market operating by itself (Hoffmann et al., 2004; Schiele, 2008).

A very important point to be noted is that a major assumption of TCT-Transaction Cost Theory is the bounded rationality and opportunism of human behavior in the evolution of enterprises in market issues. Bounded rationality means that enterprises should seek measures to save resources (e.g. money) in market development processes. Opportunism, which indicates parties involved in the commercial relation with candor and honesty in commercial platform transactions.

\subsubsection{The Structuring Aspect on Enterprises Network Platform}

(Davidow, 2003) processes of transaction cost theory provide new insights into the structuring of clusters, and suggested that enterprises cooperation is complex. As noted in this research "CCII-Commercial Cluster Integration Initiative", enterprises and governments are involved in the same objective. Thus, there is an essential networking in the transaction cost (opportunism and specific asset) and game theory (defection and sucker's payoff). The network is a fundamental cooperation issue that was mentioned earlier, which is related to market behavior integration. The level of uncertainty together with interdependence and vulnerability in the pursuit of common-gain through competitive cooperation development action in market focus can be seen. Without committed assets, a new regional integration in commercial development market cooperation has no way to deeply develop the aim market.

Also, Heide\& George (1992) argued that TCT-Transaction Cost Theory has direct relation with an enterprise structure. Transaction cost is used in enterprises internal assets and the presence of safeguards to integrate investment parties. Due to this operation Transaction Cost Theory has a strong role in several streams of marketing literature. The theory is a blend of institutional economics and organizational legal analysis.

\subsubsection{The Aspect of Government Structure Networking Support}

It can be noted in this part that TCE-Transaction Cost Economics relies on three (3) behavior assumptions in predicting how enterprises manage government's network, opportunism, bounded rationality and risk neutrality (Chu, 2004); (Lin, 1998), previously referred to.

The TCE-Transaction Cost Economics analysis of enterprises to implement a regional integration, and CCII-Commercial Cluster Integration Initiative networking platform under government conditions must to be evaluated internally on asset structure and commercial strong enterprise with a networking partner relation.

The Transaction Cost Economics (Williamson, 1975, 1985, 1991) analysis of government interaction alternatives also have to be considered in any kind of integration cluster in order to build international political support (see, for example Das and Teng (2002); Freel (2000); Jarillo (1988, 1993).

Furthermore, integration platform can be considered a continuum process in markets. In one extreme lies the regional integration market platform that produces trading resources, and in the other extreme lies the international market objective with trading networking interaction in transaction economics and cost theory behavior that determinate the final trading transaction. In other words, there are two parties in the trading transaction such as domestic market (producer) and international market (purchaser) in trading relation. (Subramony, 2006).

\subsubsection{The CCP-Commercial Cluster Platform Aspect on TCE-Transaction Cost Economic}

The expansion in the variety cluster forms that take in the functions serve. Analyses merely sought to examine the market thickness (domestic and international), hierarchies, and hybrid forms (mainly cluster agreement). Early studies and even many recent ones placed clusters administrative forms in any kind of markets and hierarchy levels (e.g., Ireland et al., 2001; Simmie and Sennett, 1999). Now scholars should consider that several kinds of clusters have to be integrated into unique network capabilities. A number of studies may see clusters as just instruments to reduce transaction cost and risk, as explained in this study; but others believe 
clusters can be implemented to develop competitiveness.

A recent study by Porter (2002), has also analyzed clusters via TCT-Transaction Cost Theory. It views transaction cost as also being used to explain three typical strategies to increase enterprises growth: integration network platform initiative, commercial competitive implementation and investment trust. The implementation of strategies among enterprises and governments can be regarded as integration strategies according to international marketsgrowth.

Although the literature has reviewed the wide advantages of TCT-Transaction Cost Theory, limitations have also been found. These will be explained in the next section.

\subsubsection{Narrow Circumstances of Transaction Cost}

Narrow circumstances can also be seen in transaction cost, as denoted by Chu (2004) in shortcoming transaction economics cost paradigm. This was presented for the simple reason that there was not a high understanding of risk and trust measure in earlier empirical and theoretical issue.

Property rights theory has also presented narrow circumstances transaction cost: accurate predictions according to partnerships management that are not accomplished (e.g. regional integration agreement). Transaction cost generally anticipates structures closer relating to hierarchy, but some empirical studies have not found this relationship at all (Li and Lin, 2006).

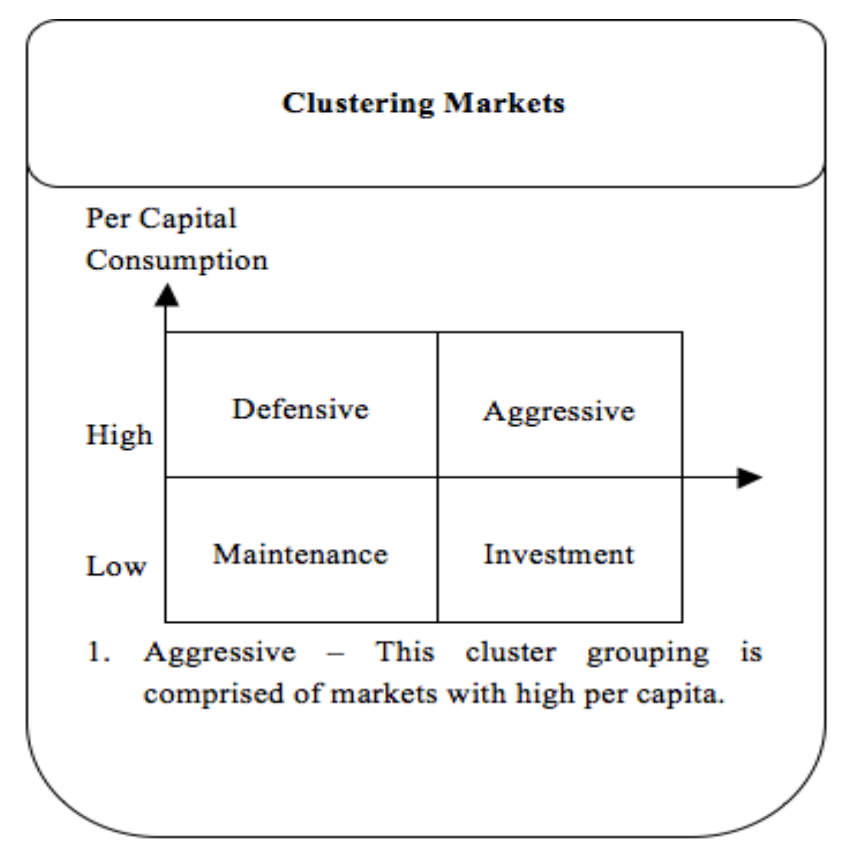

Figure 7. Clustering markets

Source: Own Researcher Data, 2012, Clustering Markets

\subsection{Model Development \& Hypotheses}

As already mentioned, the purpose of this study is to implement and develop a CCII-Commercial Cluster Integration Initiative in initiative networking among CELAC, 2011 enterprises and/or industries with China market as supply chain. The following sections will try to demonstrate how the collaboration structure for commercial integration agreement will be implemented where the parties involved are enterprises in CELAC countries integration with an objective to develop and enter freely into China supply chain market. So, the networking structure in commercial relationship will be integrated in the same region with a government support (CELAC, 2011) and union enterprises; Chinese supply chain market evolution will be analyzed as an important point in this research, even, this study can be available to be implemented with other kinds of markets such as CELAC - EU, etc. 


\subsection{Research Hypotheses}

The concept of transaction cost is important and relevant to the development of strategies in theory research, particularly with respect to knowing the reason for enterprises diversification, engaging JVs, multinational cooperation and reliance on informal agreements in operating commercial transactions ( $\mathrm{Li}$ et al., 2006; Bagchi and Skjoett-Larsen, 2005; Petersen et al., 2005; Saeed et al., 2005). Using transaction cost in the scenario of multinational enterprises in FDI-Foreign Direct Investment could be inefficient in transferring capabilities through agreements.

H1. Members of an enterprise will form part of a commercial NW-Network with government support and become more dynamic in an international strict-regulated and potential market like Chinaif they join an association witha regional commercial structure platform such as CELAC.

H2. Members of an enterprise will form part of a commercial NW-Network with government support and become more dynamic in an international strict-regulated and potential market like Chinaif they make essential coordination in implementing commercial clusters.

H3. Members of an enterprise will form part of a commercial NW-Network with government support and become more dynamic in an international strict-regulated and potential market like Chinaif they expected low levels of reciprocity.

H4. Members of an enterprise will form part of a commercial NW-Network with government support and become more dynamic in an international strict-regulated and potential market like Chinaif they make important capital investment in assets in implementing commercial platform.

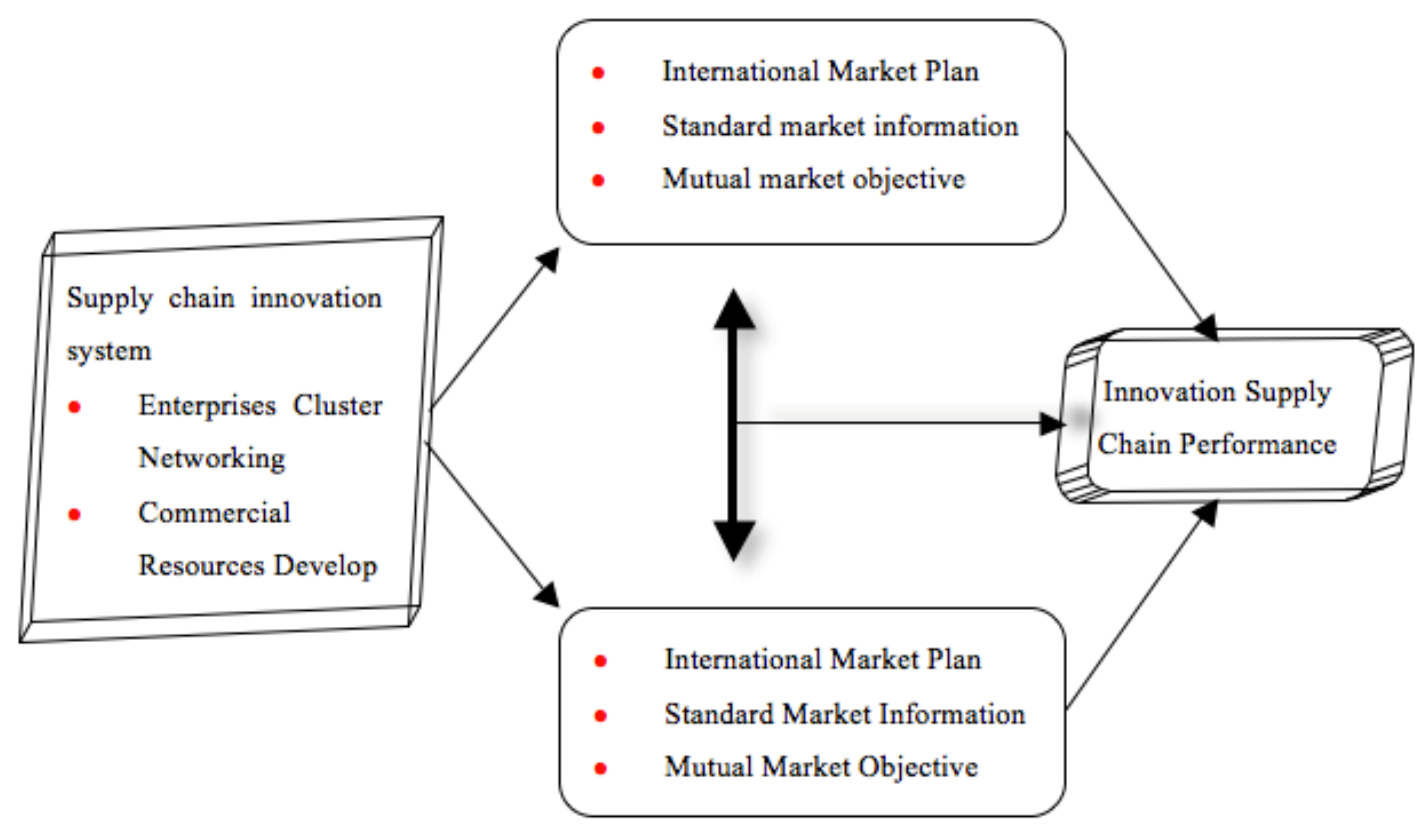

Figure 8. Research method for exploring supply chain performance

Sources: Own Researcher Data, 2012, Research Method for Exploring Supply Chain Performance

H5. Members of an enterprise will form part of a commercial NW-Network with government support and become more dynamic in getting involved in commercial platform if they make important implementation in incentive and motivation.

However, it is convenient to say that although the transactional value approach represents another theoretical framework, it is consistent with the implicit intent of the TCT-Transaction Cost Theory in some ways. Transaction costs are a subset of total costs to be aggregated and compared with the set of total benefits in an overall calculation of the commercial integration value. In this way, the second aspect related to the approach of the transactional value (to consider the process by which resources members create and develop value) becomes relevant because it can result in a transformation that leads to greater expected net benefits for every integration 
member ( $\mathrm{Li}$ and Lin, 2006). That is the reason why it can be said that the transactional value theory should be complementing the explanations of TCT-Transaction Cost Theory and the property rights theory of the selected structure for developing integration network agreement, and, thinking about the objective of this dissertation, the overall theoretical framework allows for behavior, structure, and satisfaction to be related.

H6. Members of an enterprise will form part of a commercial NW-Network with government support and become more dynamic in international strict - regulated and potential market like China if they provide satisfaction for each other in commercial cluster integration.

Having presented the theoretical framework under consideration in this dissertation, the next chapter will present the relevant data that will be used to contrast the established hypotheses.

\section{Research Methodology}

In fact, there is little literature to display this type of study focused on CCII-Commercial Cluster Integration Initiative -) platform implementation, which in this case study is related among enterprises of CELAC economic group and Chinese supply chain. Therefore, this research is designed with two different purposes: on one hand, to be exploratory research into the CCII-Commercial Cluster Integration Initiative platform implementation by enterprises of (CELAC, 2011) economic group and China supply chain; and on the other hand, to be explanatory research where government networking support (CELAC, 2011) must to be an essential part in international politics relation.

In order to understand the dynamics in CCII-Commercial Cluster Integration Initiative platform use as well as satisfaction and member's behavior, we have studied extant literature in the areas of commercial clusters. The theoretical model that was developed in Chapter Three addressed the research questions. This exercise also provides richness of contextual detail permitting grounding of the framework and constructs. Then, the data collected allowed the hypotheses mentioned in Chapter Three to be tested.

\subsection{Research Design \& Sampling Methods}

The survey was carried out with a cross-sectional design in which the data were collected in two different times. This study will be implemented in both qualitative and quantitative research. Information was conducted in the form of field research by distributing self-administered questionnaires and interviews. The purpose of the qualitative analysis is to discover how the effectiveness of knowledge transfer is affected by the measures. At the same time, the quantitative method, which is more, involved statistical and using SPSS programs version 16.0 and E-views program version to analyze data in order to confirm the findings of the qualitative analysis implementing mathematical analysis. On the other hand, the proposed determinant factors and the results of the quantitative analysis could be clarified and supplemented by a qualitative approach to achieve a more credible conclusion.

\subsubsection{Enterprises Aims and Int'1 Markets Integration Analysis}

Based on related theories and empirical research, this dissertation aims to consolidate and expand the existing few literatures on integration network amongCCII-Commercial Cluster Integration Initiative members (enterprises) and to contribute a wider body of literature to enterprises integration network. The sample consists of the "CCII-Commercial Cluster Integration Initiative". It refers to non-equity based commercial cluster network between regional enterprises (CELAC, 2011) and Chinese supply chains, where CELAC enterprises will grow their commercial \& services resources.

Table 4. Enterprises of the case study

\begin{tabular}{cc}
\hline Kind of enterprises & Enterprises participation \\
\hline Production enterprises & 125 \\
Commercial enterprises & 99 \\
Services enterprises & 45 \\
Exporting enterprises & 32 \\
Importing enterprises & 15 \\
Total & 316 \\
\hline
\end{tabular}


Source: own researcher calculation data, 2012, enterprises of the case study

\subsubsection{Sampling Techniques}

Although some kind of sampling plan should be used to identify the appropriate sample size, this study used the entire population instead. This is due to the nature of the research question of this Doctoral degree study which data were to be analyzed by factor analysis and structural equation modeling analysis. In relation to these two techniques, Hair et al. (1995) mentioned that the researcher generally would not analyze a sample of fewer than 50 observations, and preferably the sample size should be 100 or larger. As a general rule, the minimum was to have at least five observations for each independent variable or five times as many observations as there are variables to be analyzed, and the more acceptable range would be a ten-to-one ratio. In relation to the structural equation model testing, a general rule is that there should be five observations for each independent variable (Hair et al., 1998).

\subsection{Methods of Data Collection}

Based on the purposes of this research, several main sources of information have been used:

Information data of the enterprises operating across several industries was collected through industrial associations such as chamber of commerce, Council/Chamber of International Commerce, where one could manage and get relevant enterprises information according to the questionnaire. These are the best data resources of CELAC countries and China market. The objective was to create a preliminary list of enterprises and analyze relevant information of commercial clusters implementation environment at regional and international levels, which exhibit characteristics of transaction costs, implementation reasons, truth, commercial growth, government support, benefits, etc.... In cases where no enough information was available, contact was made with the enterprises to collect or reconfirm data.

Table 5. Mail survey results

\begin{tabular}{ccc}
\hline Description & Quantity & $\%$ \\
\hline Questionnaire sent (1) & 226 & $8 \%$ \\
Undeliverable questionnaires & 18 & $49.1 \%$ \\
Received questionnaires(1) & 111 & $47.8 \%$ \\
Questionnaires sent for & 108 & \\
follow-up & 74 & $32.7 \%$ \\
Questionnaires received(2) & 316 & \\
Total questionnaires sent(1)-(2) & 131 & $41.5 \%$ \\
No response & 185 & $58.5 \%$ \\
Response & 4 & $1.27 \%$ \\
Decline to participate & 7 & $2.22 \%$ \\
Unusable & 174 & $55.1 \%$ \\
Completed questionnaires & &
\end{tabular}

Source:own researcher calculation data, 2012, mailing survey results

\section{Main Findings, Conclusions and Recommendations}

The last chapter consists of five sections. The first section discusses significance of the present study including the result concerning the effectiveness of strategic CCII-Commercial Cluster Integration Initiative; useful to the supply chain of the markets. The next section is about the summary of the dissertation in order to concrete the main idea of the study. The third section presents the conclusion of the overall study. The following section then discusses the limitations of this Doctoral Philosophy study in terms of its research design and measurement. The fifth and last section provides suggestions for further research (FTA between CELAC - CHINA).

\subsection{Significance of this Doctoral Degree Research}

It is possible to say that this research will enhance the actual knowledge of (CCI-Commercial Cluster 
Integration Initiative) strategic for developing international markets as in China (study case) and the results from the study will be useful for scholars who are interested in this innovation field. Entrepreneurs, investors or existing enterprises will be able to apply this information in planning, reforming, and developing their commercial resources.

\subsection{Summary of This Dissertation}

Other theoretical frameworks such as PRT-Property Right Theory and TVT-Transaction Value Theory, that research believes complement the TCE-Transaction Cost Economics, are considered and the mix of all allows this dissertation to reach the theoretical framework of the reference. Likewise, in this theoretical framework, several hypotheses have been formulated and contrasted in Chapter Four. The results of the tests validated the theoretical framework.

As main conclusion, it can be pointed out that if different topics are considered by regional enterprises and governments network in decision making to implement CCII-Commercial Cluster Integration Initiative agreement (for example, the possible opportunistic behavior of the members, the presence of trust, the presence of forbearance, the allocation of the property rights or the future clusters results), then the satisfaction of the members is related to the specific structure of the integration network.

\subsection{Listing of the Main Conclusions}

Following the summary section, the main conclusions are stated as follow:

Satisfaction levels related to CCII-Commercial Cluster Integration InitiativeNW-Network are significantly impacted by global economy as well as regional (CELAC, 2011); within these parameters, theoretical framework of TCT-Transaction Cost Theory, PRT-Property Right Theory and TVT-Transaction Value Theory constitute a necessary support to evaluate implementation processes.

\subsection{Limitations of the Actual Doctoral Research}

The research results, although encouraging the work on enterprises boundaries, still have some limitations due mainly to the nature of the data. In this sense, the information used for measuring some aspects perhaps are not the best and it could be necessary to work more in this aspect.Furthermore, the information about CCII-Commercial Cluster Integration Initiative $\mathrm{NW}$-network is quite limited both in terms of the actual features of the selected government structure system and in the terms ofattributes identifying complexity transactions commercial resources. This study would have benefited from a more detailed description of the terms of the integration network to make sure that the coding of the variables was the correct one. This difficulty is often recognized in the literature (Oxley, 1997, p. 391). Nevertheless, it is important to bear in mind to introduce some caution in this section. However, it is possible to say that the preliminary evidence presented will encourage future efforts to collect this data and verify the robustness of the results.

\subsection{Future Research}

Then it is possible that estimates of reliability may be somewhat exaggerated. This is a relatively new view on regional commercial integration research, and of course, there is a need for further research to detail the measurement of the main development.

Future research could significantly raise the level of theory development in CCII-Commercial Cluster Integration Initiative network platform by going beyond path analysis and causal modeling that may permit a deeper understanding of the causal platform of integration network among crucial variables in commercial enterprises network. Moreover as reviewed in many studies (Ford, D., Hakansson, H. and Johnson, J. (1993); Dwyer et al. (1987; Heide and John (1992; Ganesan (1994; Wilson (1995; Batonda and Perry (2003) and theories, resource view has been proposed to account for the emergence of CCP-Commercial Cluster Platform strategy as well as its implementation. According to Zahra and Neubaum (1998), the process of integrating enterprises network can be studied as a flow of resources among industries involved.

\section{References}

Aaker, J., Fournier, S., \& Brasel, S. A. (2004). When good brands do bad. Journal of ConsumerResearch, 31(1), 1-16. http://dx.doi.org/10.1086/383419

Agndal, H., \& Axelsson, B. (2002).Internationalisation of the firm-the influence of relationship sediments. InHavila, V., Forsgren, M., and Hakansson, H. (Eds.), Critical Perspectives on Internationalisation. Pergamon, Amsterdam/New York, NY.

Bagchi, P. K., \& Skjoett-Larsen, T. (2005). Supply chain integration: a European survey. The International 
Journal of Logistics Management, 16(2), 275-94. http://dx.doi.org/10.1108/09574090510634557

Batonda, G., \& Perry, C. (2003). Approaches to relationship development processes in inter-firm networks. European Journal of Marketing, 37, 1457-84. http://dx.doi.org/10.1108/03090560310487194

Bell, J. (1995). The internationalization of small computer software firms: a further challenge to stage theories. European Journal of Marketing, 29(8), 60-75. http://dx.doi.org/10.1108/03090569510097556

Blankson, C., \& Stokes, D. (2002).Marketing practices in the UK small business sector. Marketing Intelligence \& Planning, 20(1), 49-61. http://dx.doi.org/10.1108/02634500210414774

Business Objects SA. (2007). Business intelligence platform. Retrieved from hattp://www.businessobjects. com/products/platform/default.asp?intcmp? ip_products8\#

Coviello, N. E., \& Munro, H. J. (1997). Network relationships and the internationalization process of small software firms. International Business Review, 6(4), 361-86. http://dx.doi.org/10.1016/S0969-5931(97)00010-3

Charlett, D., Garland, R., \& Marr, N. (1995). How damaging is negative word of mouth? Marketing Bulletin, 6 , 42-50.

Chen, H. C., \& Shyu, J. Z. (2005). Using ANP for evaluating value position of industrial cluster effect. 2005 International Symposium on the Analytic Hierarchy Process, Honolulu, Hawaii.

Chu, S. J. (2004). Application of transaction costs to procurement strategy-a study of the aerospace industries development cooperation. unpublished Master dissertation, University of Tunghai, Taichung.

Clark, K. B., \& Fujimoto, T. (1991). Product Development Performance. Harvard Business School Press, Boston, MA.

Daconta, C., Obrst, L., \& Smith, K. (2003). The Semantic Web: A Guide to the Future of XML, Web Services, and Knowledge Management. Wiley, Indianapolis, IN.

Das, T. K., \& Teng, B. (2002). A social exchange theory of strategic alliances, in Contractor, F.J. and Lorange, P. (Eds.), Cooperative Strategies and Alliances (pp. 429-60). Oxford: Elsevier Science.

Davenport, T. (2005). The right way to use business analytics. Retrieved from hattp://www.cio.com/article/print/12557

Davidow, M. (2003). Have you heard the word? The effect of word of mouth on perceived justice, satisfaction and repurchase intentions following complaint handling. Journal of Consumer Satisfaction, Dissatisfaction and Complaining Behavior, 16, 67-80.

Dunn, M., Birley, S., \& Norburn, D. (1987). The marketing concept and the smaller firm. Marketing Intelligence \& Planning, 4(3), 3-11. http://dx.doi.org/10.1108/eb045728

Dwyer, F. R., Schurr, P. H., \& Oh, S. (1987). Developing buyer-seller relationships. Journal of Marketing, 51, 11-27. http://dx.doi.org/10.2307/1251126

Ford, D., Hakansson, H., \& Johnson, J. (1993). How do companies interact? In Ford, D. (Ed.), Understanding Business Markets: Interaction Relationships and Networks. London: Academic Press.

Fournier, S., \& Lee, L. (2009). Getting brand communities right. Harvard Business Review, 105-11.

Freel, M. (2000). External linkages and product innovation in small manufacturing firms. Entrepreneurship \& Regional Development, 12, 245-66. http://dx.doi.org/10.1080/089856200413482

Ganesan, S. (1994). Determinants of long-term orientation in buyer-seller relationships. Journal of Marketing, 58, 1-19.http://dx.doi.org/10.2307/1252265

Garbarino, E., \& Johnson, M. S. (1999). The different roles of satisfaction, trust, and commitment in customer relationships. Journal of Marketing, 63(3), 70-87. http://dx.doi.org/10.2307/1251946

Heide, J. B., \& John, G. (1992). Do norms matter in marketing relationships? Journal of Marketing, 56, 32-44. http://dx.doi.org/10.2307/1252040

Hennig-Thurau, T., Gwinner, K. P., \& Gremler, D. D. (2002).Understanding relationshipmarketing outcomes: an integration of relational benefits and relationship quality. Journal of Service Research, 4(3), 230-47. http://dx.doi.org/10.1177/1094670502004003006

Hill, J., \& Wright, L. T. (2001). A qualitative research agenda for small to medium-sized enterprises. Marketing Intelligence \& Planning, 19(6), 432-3. http://dx.doi.org/10.1108/EUM0000000006111 
Hoffmann, W. A. M., Gregolin, J. R., \& Oprime, P. C. (2004). The contribution of competitive intelligence to the development of local productive settlements: case Jau'-SP. EncontrosBibli: RevistaEletro^ nica de Biblioteconomia e Cie^ncia da Informac, ã o.

Huang, Y., \& Chung, J. Y. (2003). A web services-based framework for business integration solutions.Electronic Commerce Research and Applications, 2(1). http://dx.doi.org/10.1016/S1567-4223(03)00007-3

Ireland, R. D., Hitt, M. A., Camp, S. M., \& Sexton, D. L. (2001). Integrating entrepreneurship and strategic management actions to create firm wealth. Academy of Management Executive, 15, 49-63. http://dx.doi.org/10.5465/AME.2001.4251393

Johnston, R. (2001). Linking complaint management to profit. International Journal of Service Industry Management, 12(1), 60-6. http://dx.doi.org/10.1108/09564230110382772

Karsak, E. E., Sozer, S., \& Alptekin, S. E. (2002). Product planning in quality function deployment using a combined analytic network process and goal programming approach.Computers \& Industrial Engineering, 44(1), 171-90. http://dx.doi.org/10.1016/S0360-8352(02)00191-2

Lai, H. C., \& Shyu, J. Z. (2005). A comparison of innovation capacity at science parks across the Taiwan strait: the case of Zhangjiang high-tech park and Hsinchu Science-based industrial park. Technovation, 25, 805-13. http://dx.doi.org/10.1016/j.technovation.2003.11.004

Lapadat, J. C. (2009). Thematic analysis. In Mills, A. J., Wiebe, E. and Durepos, G. (Eds.), Encyclopaedia of Case Study Research, 2. Sage Publications, Thousand Oaks.

Lin, J. H. (1998). An empirical study on measuring operating efficiency of securities-firms in Taiwan. Fu-Hua Quarterly Report, 58(1), 1-24.

Merchant, K., \& Otley, D. (2007).A review of the literature on control and accountability. In Chapman, C.S., Hopwood, A., and Shields, M. (Eds.), The Handbook of Management Accounting Research. Oxford: Elsevier.

Miles, M. B., \& Huberman, A. M. (2005). Qualitative Data Analysis: An Expanded Sourcebook (2nd eds.). Sage Publications, Thousand Oaks.

Miles, G., Snow, C., \& Sharfman, P. (1993). Industry variety and performance. Strategic Management Journal, 14, 163-77. http://dx.doi.org/10.1002/smj.4250140302

Osterle, H., Fleisch, E., \& Alt, R. (2001). Business networking: shaping collaboration betweenenterprises. Springer, New York, NY.

Paik, Y., Vance, C. M., \& Stage, D. H. (2000). A test of assumed cluster homogeneity for performance appraisal management in four Southeast Asian countries. International Journal of Human Resource Management, 11(4), 736-50. http://dx.doi.org/10.1080/09585190050075097

Petersen, K. J., Gary, L. R., \& Robert, M. M. (2005). An examination of collaborative planning effectiveness and supply chain performance. The Journal of Supply Chain Management, 41(2), 14-25. http://dx.doi.org/10.1111/j.1055-6001.2005.04102002.x

Porter, M. (2002). Enhancing the microeconomic foundations of prosperity: the current competitiveness index, in Porter, M.E., Sachs, J.D., Cornelius, P. K., McArthur, J.W. and Schwabb, K. (Eds.), The Global Competitiveness Report 2001-2002. Oxford: Oxford University Press.

Power, D. (2007b). Tom Davenport: competing on analytics. Retrieved from http://DSSResources. com/interviews/davenport/davenport05272007.html

Prahalad, C. K., Fahey, L., \& Randall, R. M. (2001). Creating and leveraging core competencies. In Fahey, L. and Randall, R.M. (Eds.), The Portable MBA in Strategy (2nd eds.). New York, NY: Wiley.

Rick Fernandez Hurtado, S., \& Pablo Betancur Agudelo, J. (2012). The Continuity and Stability of Corporate Philanthropy Donation: Evidence from Chinese Firms' Response to Disaster Relief. International journal of business and management, 8(2), 10-18. http://dx.doi.org/10.5539/ijbm.v8n2p10

Saeed, K. A., Malhotra, M. K., \& Grover, V. (2005). Examining the impact of interorganizational systems on process efficiency and sourcing leverage in buyer-supplier dyads. Decision Sciences, 36(3), 365-96. http://dx.doi.org/10.1111/j.1540-5414.2005.00077.x

Sala-i-Martin, X., \& Artadi, E. V. (2004). The Global Competitiveness Index. The Global Competitiveness 
Report, World Economic Forum, Geneva.

Sarkis, J. (2003). A strategic decision framework for Green supply chain management. Journal of Cleaner Production, 11(4), 397-409. http://dx.doi.org/10.1016/S0959-6526(02)00062-8

Schiele, H. (2008). Location, location: the geography of industry clusters. Journal of Business Strategy, 29, 29-36. http://dx.doi.org/10.1108/02756660810873191

Simmie, J., \& Sennett, J. (1999). Innovative clusters: global or local linkages? National InstituteEconomic Review, 170, 87-98. http://dx.doi.org/10.1177/002795019917000112

Stake, R. E. (2008).Qualitative case studies.in Denzin, N.K. and Lincoln, S.Y. (Eds.), Strategies of Qualitative Inquiry (3rd ed.). Los Angeles, Sage Publications, CA.

Stauss, B., \& Schoeler, A. (2004). Complaint management profitability: what do complaint managers know? Managing Service Quality, 14(2/3), 147-56. http://dx.doi.org/10.1108/09604520410528572

Subramony, M. (2006). Why organizations adopt some human resource management practices and reject others: an exploration of rationales. Human Resource Management, 45(2), 195-210. http://dx.doi.org/10.1002/hrm.20104

Williamson, O. E. (1975). Markets and Hierarchies. New York: Free Press.

Wilson, D. T. (1995). An integrated model of buyer-seller relationship. Journal of the Academy of Marketing Science, 23, 335-45. http://dx.doi.org/10.1177/009207039502300414

Williamson, O. E. (1985). The Economic Institutions of Capitalism. New York: Free Press.

Yin, R. K. (2008). Case Study Research: Design and Methods ( $4^{\text {th }}$ ed.). Sage Publications, Thousand Oaks, CA.

Zhang, J., \& Bloemer, J. M. M. (2008). The impact of value congruence on consumer-service brand relationships. Journal of Services Research, 11(2), 161-78. http://dx.doi.org/10.1177/1094670508322561

Zahra, S., \& Newbaum, D. O. (1998). Environmental adversity and the entrepreneurial activities of new ventures. Journal of DevelopmentalEntrepreneurship, 3(2), 123-140. 